\title{
Expanded Education and Global Integration: Solidarity and Conflict ${ }^{1}$
}

\author{
David John Frank (University of California Irvine) \\ and John W. Meyer (Stanford University)
}

\begin{abstract}
:
The dramatic expansion and rising social significance of education integrates the world's populations and elites under a common ontological frame and on the basis of common human identities rooted in educational status and cultural content. Education-based integration supports institutions of solidarity - large-scale organizational structures in national and global societies, and common cognitive and normative cultural materials. It also creates expanded grounds for conflict. In this essay, we review the matter.
\end{abstract}

Keywords:

conflict; education; integration; solidarity; world society

\section{A Globalized Schooled Society}

Education has expanded and become a global institution, rapidly in the period since World War II, and even more in the neoliberal period since around 1990 (Baker, 2014; Lerch et al., 2019). A number of dimensions of globalization and expansion are relevant.

1. Standardized forms: The baseline change is the global rise and diffusion of standardized educational organizations with standardized degrees. Virtually everywhere now, there are pre-schools, primary schools, secondary schools (junior and senior), universities, and graduate schools, and virtually everywhere they have shared meaning, such that UNESCO can report educational data in unified tabular schemes. Indeed, local educational organizations derive significance from their status as instances of global institutions (Frank \& Meyer, 2020). Were one to teleport from a classroom in Manila to a classroom in Montréal, the culture shock would be minimal. Of course, there are some variations within and between countries, but almost all are legible - and increasingly so. The specialized and distinctive organizations that persist, such as schools of dance or schools for the deaf, are exceptions to the rule. For the most part, around the world, a school is a school is a school, and schools are everywhere.

2. Participation: Hand in hand with the rise of standardized educational forms is the explosion of enrollment. This now seems inevitable and commendable, as expressed, for example, in the Education for All movement. Primary education has become almost universal, and limitations on it are treated as failures of progress and justice
(Meyer et al., 1992). Secondary education likewise has moved toward universality (Barro \& Lee, 2015). At the same time, university enrollments have exploded worldwide, to the point where nearly forty percent of young people now participate (Schofer \& Meyer, 2005). Beyond the regular school cycle, lifelong learning has grown routine (Jakobi, 2011), and preschool enrollments have skyrocketed (Wotipka et al., 2017). School-like arrangements have extended to touch even the beginnings and ends of the lifecourse, with pre-natal and death education programs. Schools are standard everywhere, and so is going to them.

3. Content: As education encompasses more people, so does it also encompass more culture, commandeering evergreater territories in the meaning system. By unfortunate conventional definition, "culture" typically signifies that which is distinctive about local customs and beliefs, thus omitting academic materials. But the rise of education entails the elaboration of shared ontological and epistemological models of society, nature, and the cosmos. Indeed, educational contents are strikingly similar around the world. Elementary and secondary school curricula are heavily patterned (Benavot et al., 1991; Kamens et al., 1996), such that testing schemes from the Program for International School Assessment (PISA) and International Educational Achievement (IEA) can be applied anywhere. Tertiary curricula likewise reflect set models (Frank \& Meyer, 2020), so much so that it becomes routine to rank universities on a unitary scale of conformity to worldclassness standards. Educational culture is world culture.

4. Universalism: Education not only transmits standardized contents around the world; it does so on a bed 
of universalism. This involves first an assertion about the objects of educational inquiry - the universality of the universe - our common sun, our common DNA, even our common grief. It involves, second, an assertation about the quality of academic understandings, which transcend the mundane world of practical skill and technique with theorized meta-world principles of universalism and rationalism (Frank \& Meyer, 2020). In other words, contemporary world education is not only standardized in content - it is also universalistic in orientation, and it explicitly claims to be so. Many particularistic forms of education and training have existed throughout history, but what we now call education, with its universalistic vision, has won out.

5. Social status: In previous periods, social stratification had local determinants: relative economic standing (income, wealth), political and cultural traits (office, ethnicity, religion), family qualities (background, reputation), and combinations thereof embedded in occupation. Over recent decades, social stratification has developed a new and global and increasingly paramount dimension - education (Shavit et al., 2007). Almost everywhere now, the masses are schooled, and the elites are very highly schooled. Education is exalted, and so are the educated, and its content is culturally central as a means to, as well as definition of, success and its accoutrements.

All these aspects of global educational expansion lay the groundwork for an increasingly integrated world society. And integration seeds solidarity and conflict.

\section{Globalized Solidarities and Conflicts}

The conventional literature typically has treated solidarity as the opposite of conflict, and it has implanted both in the primordial soils of ascribed characteristics, such as nationality, religion, and ethnicity. We take a different approach here, envisioning solidarity and conflict as mutually dependent (Simmel, 1955) and stressing their global and educational antecedents.

Education supplies common identities, rife with modern standing and personhood. And it supplies universalized frames, applicable to more and more contexts. These enable educated people everywhere to participate extensively in public and associational life and to deploy opinion and action on widespread bases. As homogenizing global educational culture absorbs more meaning and more people, these participatory inclinations and capabilities rise and motivate expanded thoughts and actions on a worldwide scale. Global solidarities and globalized conflicts ensue.

1. Organization: Fueled by education, organizational structures of all sorts - public, private, and many types of "non-profits" - expand within almost all national societies and rise exponentially at supra-national levels (Boli \& Thomas, 1999; Bromley \& Meyer, 2015). There appear vastly more inter-governmental organizations than formerly.
The booming of nongovernmental organizations is even more extreme, as is the striking expansion in multinational firms (Fitzgerald, 2015). All these kinds of supranational organizations were rare in earlier periods and thought to be hamstrung by cultural differences. But on the platforms of globalized schooled society, they pop up easily and frequently - obviously held together by the seamlessly constructed identities and frameworks of formerly very distinct peoples and contexts. Supra-national organizations are clearly the provinces of educated elites, and they sometimes provoke resistance from groups - often less educated - loyal to the old national state structures.

The rise and spread of massive organizational systems the organization of the world - generates global forms of solidarity and conflict across economic, political, educational, religious, recreational, and ideological domains, many directly constructed of educational materials. Action on a global level follows from these conditions and easily can be coordinated. But of course, the same processes can generate very large-scale conflicts - between states, economic organizations, cultural and religious structures, and so on. Formerly overlooked matters, such as practices of female circumcision, can arouse outpourings of unity (e.g., around human rights) and equally dramatic confrontations (e.g., around cultural imperialism) (Boyle, 2002). Educational integration facilitates global organization, and global organization expedites solidarity and conflict.

2. Association: Beyond formalized organizations, more education of the modern participatory sort leads to a panoply of associational structures, strikingly even at supra-national levels. The most common of these are the most tamed by, or derivative of, schooling: a world mass of professional associations doing education, research, medicine and health, recreation, and religious or religious-like matters. They are the domain and usually the creation of educated people, bound together by ideologies of similarity and common interest. But antagonisms abound, and even extreme conspiracy theories may diffuse, supported by the cultural pretenses of schooling. Thus, every institution of world society is flanked by supportive and hostile supra-national associations: for and against sexual freedoms, markets, globalism and nationalism, the social and natural sciences, and so on (e.g., Velasco, 2021).

3. Movements: At the periphery of this mass of organizations and associations, which embody the rationalized and empowered actorhood of the educated, are more inchoate social movements, reflecting patterns of solidarity and conflict of less structured sorts. In a world where humans are integrated through common schooled identities and interconnected by education-based literacy and global lingua franca, unexpected themes of abstract and putatively universal character can sweep through the social system, beyond disciplined available organizational structures, spawning solidarities and conflicts worldwide. 
The \#MeToo movement made a global impact almost immediately, for example.

The efflorescence of movements is especially striking in a stateless world polity, lacking any centralized power structure. Even without a consolidated state, however, global movements swiftly spring up, enabled by spectacularly rich supplies of common, educationally constructed identities and ideas. Educated individuals are known to mobilize around universalized identities and abstractions far beyond local meanings and first-hand experiences. They stake claims and organize activities around phenomena manifested only, or mainly, in school classrooms and laboratories - a language virtually no one speaks or an ozone hole almost no one has seen. A schooled person can mobilize hatred, and love, for categories of people that unschooled people know nothing about.

4. Theories: Behind the welters of organizations, associations, and movements, which fill the contemporary world with demonstrations of common and schooled human hubris, lie the great explanatory schemes that interpret it all. Formerly religious in character, and in a sense parochial, these are now mainly organized around the transcendent gods of Research and Theory, rooted in school-based epistemologies and ontologies. As such, they diffuse facilely throughout the world and trigger oscillations of solidarity and conflict. Theoretical frameworks no longer restrict their scopes to local questions and answers: they are grande and grandiose. They imagine Great Problems and correspondingly Great Solutions. People can organize around them worldwide and can oppose them with worldwide reactions. We can note a few:

a. People can find theories, promulgated and diffused through educated people and their empowered status, on normative and cognitive matters related to the natural environment. For instance, Hindu traditions entirely aside, theorized discourses related to the cow can go worldwide: cows produce the greenhouse gas methane, they consume water and use up agricultural land inefficiently, and they are treated inhumanely; but cows also produce nutrient-rich milk and protein, preferred by some medicalized diets.

b. Similarly, education warrants the assembly of highly theorized doctrines of economic organization, which enable national and global mobilization. On one side, there arises the World Economic Forum; on the other side, the World Social Forum. On both sides, there are educated ideologies and professionals. Abstract models elevate formerly local issues - around work, pay, food, or taxes, for example - into instances of global efficiency or injustice.

c. Notions of human rights, formulated in universalistic terms, can inspire local mobilizations and link them up to global ones. The proposition of "human" and the conjecture of "rights" are already spectacular acts of theorization, heavily dependent on educational engineering, all the more so with their conjunction into "human rights." The abstractions decimate many distinctions based on citizenship, culture, and national origin, and they provoke equal measures of advocacy and dissent.

In all these cases, expanded education stitches together cognitive frames, and it supports professional - often scientized - bases for global solidarity and conflict. Populations are interlinked under general rules, supported by the schooled knowledge system.

\section{Common Identities and Frameworks}

All the processes we discuss here create linkages of global solidarity. Professions and organizations supported by education permit people and groups to find common cause across a wide and expanding array of issues.

But in aggregating knowledge and interest to global levels, the same processes aggregate conflicting models and interests, and transmit well theorized global conflicts down into local society. Local people can formulate their positions in well-schooled global terms, and global conflicts can reach down into local arenas. A minor household dispute over who takes out the garbage can explode into universalized claims rooted in the UN Declaration of Human Rights. We note several interrelated processes:

a. Education supports huge infusions of material into the global commons. A cherished baobab tree, for instance, may be loaded with schooled meaning - no longer just a source of nectar for nearby bushbabies but also an instance of a species threatened by climate change and habitat loss, a thread in the web of life. As schooled ideologies convert local resources into global commons, they build rationales for concordance and discordance alike. There is more on which to agree and more over which to disagree.

b. Education fuels huge increases in the supplies of empowered actorhood, in part by imposing causal structure on the universe and in part by imbuing people with understanding and authorial capacity over it (Frank \& Meyer, 2020). As schools disperse reason and the human authority to apply it, they populate the world with actors who claim and are commonly accorded standing. Like high-grade magnets, actors gravitate with great force toward action, or at least actorhood. One changes the world through composting, another does yoga, a third leads a coup d'état.

c. Education seeds conflict not only by enlarging the global commons and populating it with global actors but also by reconstituting the global stratification system. As ever more of the most desirable positions in society come to require academic credentials, anti-school populists rebel against the monopoly status of the educated elite. To a striking extent, current anti-liberal reactions are 
focused on education, not the obvious and extreme economic and political inequalities. Harvard may be a more potent negative icon than Goldman Sachs.

Again, we call attention to the two-sided quality of global educational integration. It stokes solidarity and conflict alike.

\section{Prospects}

The education-based integrations we discuss above extend and metamorphose longtime modern processes. The rise and global spread of the modern nation-state was a major movement in the transformation of fragmented local societies into integrated and solidary nations. Earlier changes had created unified elites across vast geographical areas, but not whole integrated societies. Nation-building aggregated little clusters of humans into great nations - making "peasants into Frenchmen," in the words of Eugen Weber (1976). The postwar extension of this system to the whole world set similar processes in motion everywhere. Increasingly, people acquired broad-based solidarities, incorporating national identities transcending local ones. Most fundamentally, one could kill or die for the national state, but not local kin and community. Thus, there was great destruction of local cultural arrangements, and the number of gods around the world plummeted.

The whole history of national solidarity is, however, built on and accompanied by massive amounts of conflict and violence - the "civic culture" rests on a towering pile of skulls. The forces of nationalism arose from and themselves produced murderous and supra-rational wars between the rising states (Hironaka, 2017; Tilly, 1990). And they produced extraordinarily bloody conflicts within the national states: after the second world war, expansion into the world's peripheries made civil war endemic - something that carries on to this day (Hironaka, 2005).

The most recent century of development of this system extends the same process to the global level, though nothing like a stable world state or even effective polity is in the offing. The dramatic processes of integration, however, go on apace. Forces of world solidarity are everywhere apparent: great human rights programs, environmental movements, expansions of international legal and accounting systems, and demands for social justice on all fronts. Leading the way is world education, carrying common cultural notions to the populace, and common standards of knowledge and rationality to elites. In all these areas the world is vastly more integrated than formerly, and individuals can - as expressed in the opinion surveys that now cover the globe - articulate their commonalities and common knowledge across ever more domains.

But this extraordinarily expansive century has also been produced by and productive of extraordinary and enflamed conflict: world wars, a threatening cold war, and murderous nationalisms with repeated cycles of harrowing genocide. The same forces that produce expansive solidarity at highly aggregated levels also produce destructive conflicts at higher and higher levels, not only between global and local but also between global and global. Conflicts over recent decades both domestic and international - are increasingly formulated as world conflicts. They are highly theorized and generalized and threatening because they occur between near competitors, willing to destroy the world over details like the exact organizational ownership of capital, the precise borders between countries (including claims to deserted islands and uninhabitable mountains), the boundaries between the genders, or the names and properties of prevailing gods. With education, people go nuclear: they gain the capability to control and demolish. Educated modern actors and their structures have the ability to destroy life on Earth, and the exalted actorhood to legitimate doing it. The very same capacity to imagine and construct universal solidarities across peoples and lifeforms and land masses - enables extraordinary conflict. The most destructive conflicts, of course, are animated by advocates of the greatest and sometimes genocidal solidarities.

\section{References}

Baker, D. (2014). The schooled society: The educational transformation of global culture. Stanford University Press.

Barro, R. J., \& Lee, J.-W. (2015). Education matters: Global schooling gains from the 19th to the 21st century. Oxford University Press.

Benavot, A., Cha, Y.-K., Kamens, D., Meyer, J. W., \& Wong, S.-Y. (1991). School knowledge for the masses: World models and national curricula, 1920-1986. American Sociological Review, 56(1), 85-100. https://doi.org/10.2307/2095675

Boli, J., \& Thomas, G. M. (1999). Constructing world culture: International nongovernmental organizations since 1875. Stanford University Press.

Boyle, E. H. (2002). Female genital cutting: Cultural conflict in the global community. Johns Hopkins University Press.

Bromley, P., \& Meyer, J. W. (2015). Hyper-Organization: Global organizational expansion. Oxford University Press.

Fitzgerald, R. (2015). The rise of the global company: Multinationals and the making of the modern world. Cambridge University Press.

Frank, D. J., \& Meyer, J. W. (2020). The university and the global knowledge society. Princeton University Press. 
Hironaka, A. (2005). Neverending wars: The international community, weak states, and the perpetuation of civil war. Harvard University Press.

Hironaka, A. (2017). Tokens of power: Rethinking war. Cambridge University Press. https://doi.org/10.1017/9781316796290

Jakobi, A. P. (2011). Political parties and the institutionalization of education: A comparative analysis of party manifestos. Comparative Education Review, 55(2), 189-209. http://doi.org/10.1086/657931

Kamens, D., Meyer, J. W., \& Benavot, A. (1996). Worldwide patterns in academic secondary education curricula. Comparative Education Review, 40(2), 116-138. https://doi.org/10.1086/447368

Lerch, J., Bromley, P., \& Meyer, J. W. (2019). The expansive educational consequences of global neoliberalism. Working Paper, Department of Sociology, University of California, Irvine.

Meyer, J. W., Ramirez, F. O., \& Soysal, Y. N. (1992). World expansion of mass education, 1870-1980. Sociology of Education, 65(2), 128-149. https://doi.org/10.2307/2112679

Schofer, E., \& Meyer, J. W. (2005). The worldwide expansion of higher education in the twentieth century. American Sociological Review, 70(6), 898-920. https://doi.org/10.1177/000312240507000602

Shavit, Y., Arum, R., \& Gamoran, A. (2007). Stratification in higher education. Stanford University Press.

Simmel, G. (1955). Conflict and the web of group affiliations. Free Press.

Tilly, C. (1990). Coercion, capital, and european states, AD 990-1990. Blackwell Publishing.

Velasco, K. (2021). Caught in the web: How transnational networks (un)do LGBT rights. Doctoral thesis, Department of Sociology, University of Texas.

Weber, E. (1976). Peasants into Frenchmen. Stanford University Press.

Wotipka, C. M., Jarillo Rabling, B., Sugawara, M., \& Tongliemnak, P. (2017). The worldwide expansion of early childhood care and education, 1985-2010. American Journal of Education, 123(2), 307-339. https://doi.org/10.1086/689931

\title{
Recommended Citation
}

Frank, D. J., \& Meyer, J. W. (2021). Expanded education and global integration: Solidarity and conflict. On Education. Journal for Research and Debate, 4(10). https://doi.org/10.17899/on_ed.2021.10.1

\begin{abstract}
About the Authors
David John Frank is Professor of Sociology at the University of California, Irvine. His work analyzes the dynamic structure of world society, including evolving models of society, nature, personhood, sex, and knowledge. In 2020 together with John W. Meyer, he published a book on The University and the Global Knowledge Society (Princeton). Current projects focus on postliberalism, gender, academic freedom, and the emergence of gay public life in countries around the world.

John W. Meyer is Professor of Sociology, emeritus, at Stanford. He has studied the impact of global models of society (World Society, Oxford, 2009: Jepperson \& Meyer, Institutional Theory, Cambridge, 2021). Main foci have been on the worldwide expansion of education and science (Drori, et al., Science in the Modern World Polity, Stanford, 2003; Frank and Meyer, The University and the Global Knowledge Society, Princeton, 2020), and the organizational impact of globalization (Drori et al., Globalization and Organization, Oxford, 2006; Bromley and Meyer, Hyper-Organization, Oxford, 2015).
\end{abstract}

\footnotetext{
${ }^{1}$ Work on this essay was supported by the National Research Foundation (Korea): NRF-2017S1A3A2067636.
} 